\title{
ANALISA PENGARUH KUALITAS LAYANAN TERHADAP KEPUASAN PELANGGAN DALAM MEMBENTUKLOYALITAS PELANGGAN \\ ( Studi kasus: PT.Telkomsel Cirebon)
}

\author{
Tantri Wahyuni \\ Teknik Industri, Fakultas Teknik, Universitas Majalengka \\ Tantri_wahyuni80@yahoo.co.id
}

\begin{abstract}
Abstraksi
Salah satu sektor industri yang berada pada situasi persaingan yang ketat adalah industri Telekomunikasi, tidak terlepas dari masalah bagaimana mempertahankan pelanggan agar tidak berpindah ke operator yang lain (churning). Indikator yang menunjukkan tingkat kesulitan dalam mempertahankan pelanggan adalah kecenderungan pada pelanggan pra-bayar yang tidak aktif mengisi ulang pulsa hingga mencapai $40 \%$. Tujuan dari penelitian ini adalah untuk menganalisis bagaimana kualitas layanan dapat mempengaruhi kepuasan pelanggan dalam membentuk loyalitas pelanggan. Penelitian ini menggunakan non-probability sampling dengan teknik purposive. Instrumen dari penelitian ini menggunakan kuesioner yang dianalisis dengan Structural Equation Modelling : Amos versi 22. Hasil penelitian menunjukkan bahwa lima dimensi yaitu Reliability, Assurance, Tangibles, Empathy dan Responsiveness positif mempengaruhi Kualitas Pelayanan. Hasil lain menunjukkan bahwa Kualitas Layanan mempengaruhi Kepuasan Pelanggan ( C.R=4,055). Ini berarti bahwa semakin baik call quality, value added service, procedure, customer support, tarif telepon dan sms yang semakin murah, maka pelanggan akan semakin puas. Didukung oleh incumbent advantage dari PT. Telkomsel yang memiliki network dan infrastruktur yang sudah terbangun luas, sehingga saat melakukan voice phone, PT. Telkomsel memiliki kekuatan sinyal dan kualitas suara yang jernih . Kualitas Layanan mempengaruhi Loyalitas Pelanggan $(C . R=4,445)$. Keberhasilan dari pengaruh ini ini ditandai dengan adanya penurunan dalam perpindahan pelanggan (churn rate yang semakin rendah). Kepuasan Pelanggan mempengaruhi Loyalitas Pelanggan $(C . R=4,900)$. Artinya, semakin pelanggan merasa puas atas kejujuran dalam menetapkan tarif, yaitu percakapan dan sms, maka mereka akan semakin loyal.
\end{abstract}

Kata kunci: Kualitas Layanan, Kepuasan Pelanggan, Loyalitas Pelanggan dan Structural Equation Modelling

\section{PENDAHULUAN}

Salah satu sektor industri yang berada pada situasi persaingan yang ketat adalah industri telekomunikasi. Indikator yang menunjukkan tingkat kesulitan dalam mempertahankan pelanggan adalah kecendrungan pada pelanggan pra-bayar yang tidak aktif mengisi ulang pulsa hingga mencapai 40\%.Pelanggan telepon seluler di Indonesia begitu mudah untuk berganti nomor telepon keoperator lain ( churn rate) yang tinggi atau terjadi masalah disloyalty yang tinggi. Oleh karenanya, operator perlu memahami dimensi- dimensi yang mempengaruhi loyalitas pelanggan, sehingga ketika terbuka peluang bagi pelanggan untuk berpindah operator tanpa harus berganti nomor, perusahaan dapat mengantisipasinya dengan baik.Menurut Turel dan Surenko( 2004), kualitas layanan merupakan salah satu faktor yang memiliki pengaruh positif terhadap loyalitas pelanggan pada industri telekomunikasi seluler. Menurut Sharma (2003) dan Bruhn\&Grund (2000), kepuasan pelanggan berpengaruh positif terhadap loyalitas pelanggan. Dengan kata lain, kepuasan pelanggan merupakan prediktor yang mempengaruhi loyalitas pelanggan Dabholkar \& Walls (1999).

Kepuasan pelanggan merupakan kunci dalam menciptakan loyalitas pelanggan. Banyak manfaat yang diterima oleh perusahaan dengan tercapainya tingkat kepuasan pelanggan yang tinggi, yakni selain dapat meningkatkan loyalitas pelanggan tapi juga dapat mencegah terjadinya perpindahan pelanggan. Semakin pelanggan dihadapi dengan lebih banyak alternatif produk, harga dan kualitas yang bervariasi,maka semakin tinggi tingkat persaingan, sehingga pelanggan akan selalu 
mencari nilai yang dianggap paling tinggi dari beberapa produk untuk dijadikan pilihan (Kotler,2005). Kualitas yang rendah akan menimbulkan ketidakpuasan pada pelanggan, hal ini berdampak pada orang lain. Karena pelanggan yang kecewa akanbercerita paling sedikit kepada 15 orang lainnya.

Pertumbuhan industri telekomunikasi seluler di Indonesia menunjukkan perkembangan yang relatif pesat, menurut data Januari 2005, jumlah pelanggan diperkirakan sebesar 31 juta orang dan pada tahun 2012, jumlah pelanggan mencapai 125 juta orang ( annual report PT.Telkomsel 2012). Melihat indikasi ini, menunjukkan adanya peluang besar bagi bisnis telekomunikasi seluler untuk tumbuh. Iklim kompetisipun semakin terasa dengan bermunculannya berbagai operator seluler.

Dari sekian banyak industri telekomunikasi seluler di Indonesia,saat ini yang mendominasi pangsa pasar yakni PT.Telkomsel. Hingga bulan Januari 2005, PT.Telkomsel mendominasi pangsa pasar sebesar $56 \%$, selanjutnya disusul oleh PT. Indosat sebesar 33\% dan PT.Exelcomindo Pratama sebesar 12\% (Rohayati, 2006). Agar dapat unggul dalam kualitas produk dan layanan, PT. Telkomsel menggunakan standar teknologi 4G yang didalamnya terkandung kemampuan untuk melakukan pengiriman gambar dan data dengan kecepatan tinggi.

\section{METODE PENELITIAN}

Pada penelitian ini, yang menjadi target populasi adalah pelanggan Telkomsel yang ada dikota Cirebon yang telah melakukan pembelian ulang pulsa minimal 3 kali padatahun 2014.Keseluruhan populasi tidak mungkin dapat diteliti karena keterbatasan biaya, tenaga, dan waktu. Oleh karena itu, pengambilan sampel dapat mewakili sebuah populasi (Cooper dan Schindler, 2003). Pada penelitian ini, besarnya sampel disesuaikan dengan model analisis yang digunakan yaitu Structural Equation Modelling (SEM).

Berkaitan dengan hal tersebut, ukuran sampel untuk SEM yang menggunakan model estimasi Maximum Likelihood Estimation (MLE) adalah 100-200 sampel (Ghozali, 2008). Merujuk pada pendapat Hair dkk. (2006), ukuran sampel dalam penelitian harus memiliki jumlah sampel minimum lima kali jumlah pertanyaan yang dianalisis. Pada kuesioner penelitian ini terdapat
36 pertanyaan. Pada penelitian ini jumlah responden yang diambil sebanyak 150 responden sehingga dalam penelitian ini sudah dianggap mencukupi.

Adapun penarikan sampel dilakukan dengan metode non probability sampling, yakni pelanggan Telkomsel dikota Cirebon yang memenuhi kriteria populasi dan memiliki peluang/ kesempatan yang sama untuk dipilih sebagai sampel (Malhotra, 2004). Dengan teknik purposive.

Dalam model analisis ini, terdapat independent variable dan dependent variable. Independent variable adalah variabel yang mempengaruhi variabel terikatnya, dependent variable merupakan variabel yang dapat diukur, diprediksi, atau dengan kata lain dapat dimonitor dan diharapkan dipengaruhi oleh variabel bebas (Cooper dan Schindler, 2006). Model penelitian terlihat pada gambar 1 .

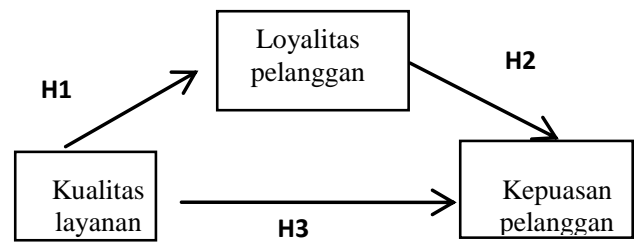

Gambar 1. Model Analisa

Sumber: Zeithaml et. al (1996); Oliver(1997).

Dugaan yangdapat dirumuskan pada penelitian ini adalah:

H1: Semakin tinggi kualitas layanan yang diberikan Telkomsel,semakin tinggi pula tingkat kepuasan yang dirasakan pelanggan Telkomsel di kota Cirebon.

$\mathrm{H} 2$ : Semakin tinggi kualitas layanan yang diberikan, semakin tinggiloyalitas pelanggan pada Telkomsel.

H3: Semakin tinggi tingkat kepuasan pelanggan, maka semakin tinggi pula tingkat loyalitas pelanggan pada Telkomsel Cirebon.

\section{HASIL PEMBAHASAN}

Metode yang dilakukan dalam penelitian ini menggunakan Metode Maximum Likelihood Estimation (MLE).

Metode ini merupakan metode estimasi yang seringdigunakan untuk analisis data dengan menggunakanmetode Structural Equation Modelling (SEM) yangdinilai lebih efisien dan 
unbiased jika asumsi normalitasmultivariat terpenuhi. Untuk selanjutnya akan diuji apakah model fit dengan data serta mengetahui hubunganyang ada antar konstruk. Tapi sebelumnya akan disusunterlebih dahulu diagram jalur dan persamaan strukturalnya.

Tabel 1. Operasionalisasi konsep service quality

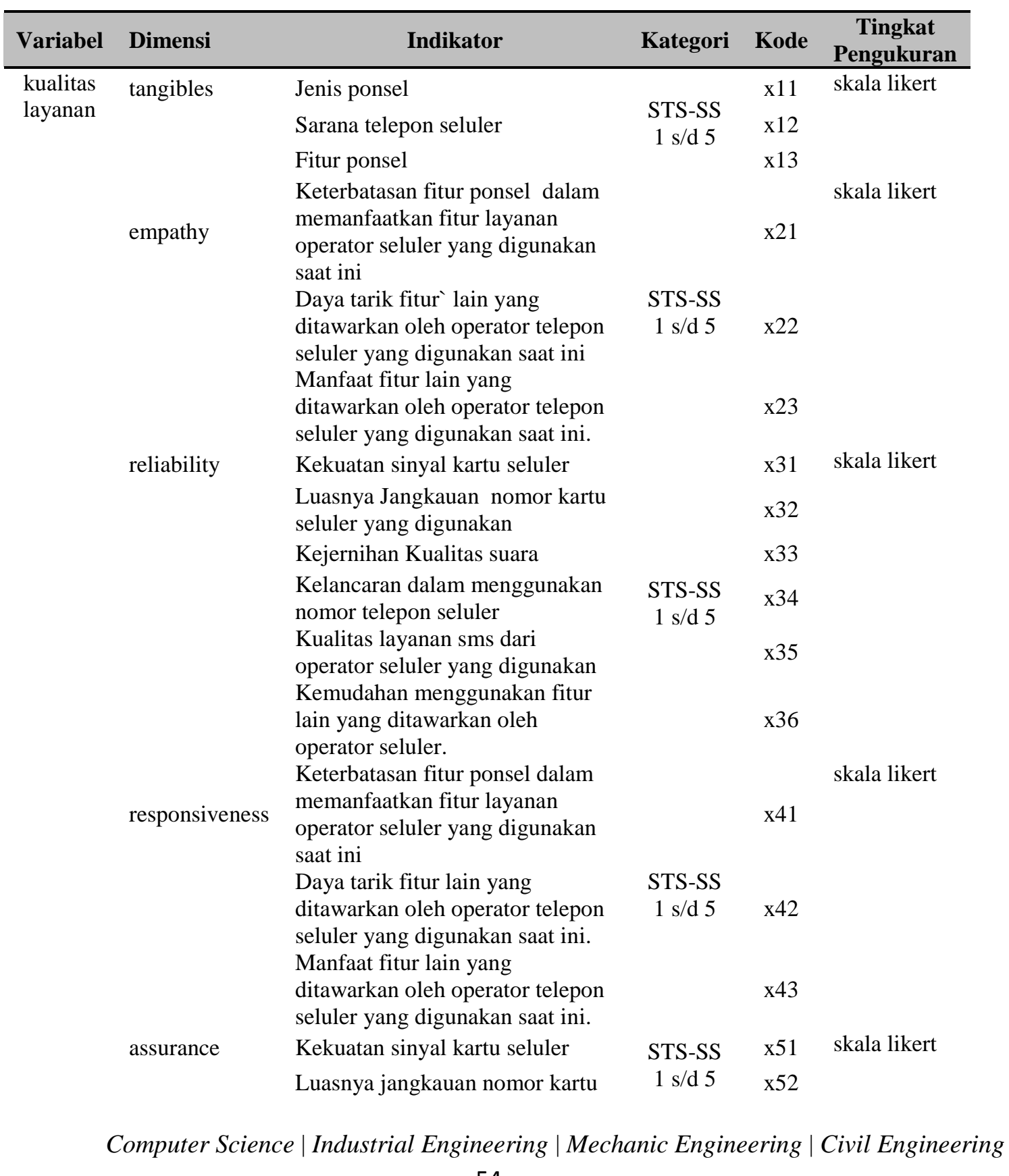




\begin{tabular}{|c|c|c|c|c|}
\hline Variabel Dimensi & Indikator & Kategori & Kode & $\begin{array}{c}\text { Tingkat } \\
\text { Pengukuran }\end{array}$ \\
\hline & yang digunakan & & & \\
\hline & Kejernihan kualitas suara & & $\times 53$ & \\
\hline & $\begin{array}{l}\text { Kelancaran dalam menggunakan } \\
\text { nomor telepon }\end{array}$ & & $x 54$ & \\
\hline & $\begin{array}{l}\text { Kualitas layanan sms dari } \\
\text { operator seluler yang digunakan }\end{array}$ & & $\mathrm{x} 55$ & \\
\hline & $\begin{array}{l}\text { Kewajaran tarif /biaya } \\
\text { percakapan }\end{array}$ & & x56 & \\
\hline & $\begin{array}{l}\text { Keakuratan perhitungan tarif } \\
\text { percakapan }\end{array}$ & & $x 57$ & \\
\hline & $\begin{array}{l}\text { Keuntungan diskon tarif } \\
\text { percakapan. }\end{array}$ & & x58 & \\
\hline & Kemudahan menggunakan fitur lain & & x59 & \\
\hline \multirow[t]{6}{*}{ kepuasan pelanggan } & $\begin{array}{l}\text { Puas atas perhitungan biaya } \\
\text { percakapan }\end{array}$ & & Y11 & skala likert \\
\hline & Puas atas biaya sms & & Y12 & \\
\hline & $\begin{array}{l}\text { Puas atas kejujuran menetapkan } \\
\text { tariff }\end{array}$ & STS-SS & Y13 & \\
\hline & $\begin{array}{l}\text { Puas atas proses pembayaran } \\
\text { pulsa }\end{array}$ & $1 \mathrm{~s} / \mathrm{d} 5$ & Y14 & \\
\hline & Puas atas penanganan keluhan & & Y15 & \\
\hline & $\begin{array}{l}\text { Puas atas bantuan layanan } \\
\text { pelanggan }\end{array}$ & & Y16 & \\
\hline \multirow[t]{6}{*}{ Loyalitas Pelanggan } & $\begin{array}{l}\text { Semangat untuk mengisi ulang } \\
\text { pulsa }\end{array}$ & & Y21 & skala likert \\
\hline & $\begin{array}{l}\text { Membeli kartu perdana yang baru } \\
\text { apabila operator seluler yang } \\
\text { digunakan menawarkan } \\
\text { promo/paket seluler yang baru }\end{array}$ & & Y22 & \\
\hline & $\begin{array}{l}\text { Senang menggunakan fitur selain } \\
\text { percakapan dan sms yang } \\
\text { digunakan }\end{array}$ & & Y23 & \\
\hline & $\begin{array}{l}\text { Senang memperbarui } \\
\text { penggunaaan fitur }\end{array}$ & $\begin{array}{l}\text { STS-SS } \\
1 \mathrm{~s} / \mathrm{d} 5\end{array}$ & Y24 & \\
\hline & $\begin{array}{l}\text { Mereferensikan pada teman untuk } \\
\text { menggunakan kartu seluler yang } \\
\text { digunakan saat ini }\end{array}$ & & Y25 & \\
\hline & $\begin{array}{l}\text { Semangat untuk menjelaskan } \\
\text { kepada rekan dan kerabat tentang } \\
\text { segala keuntungan yang terdapat } \\
\text { pada kartu seluler yang } \\
\text { digunakan saat ini }\end{array}$ & & Y26 & \\
\hline
\end{tabular}

\subsection{Uji Measurement Model}

Setelah sebuah model dibuat, tahapan selanjutnya adalah pengujian sebuah model.Tujuan pengujian adalah untuk mengetahui seberapa tepat variabel-variabel manifes dapat menjelaskan variabel laten yang ada.Hasilnya sebagaimana ditunjukkan pada gambar 2.

Pertama, menilai Goodness of Fit.Hasil perhitungan model SEM menghasilkan indeksgoodness of fit sebagaimana ditunjukkan padatabel 2.Berdasarkan tabel 2, dapat dilihat bahwa nilai chi-squares menunjukkan hasil yang baik. . Kriteria Goodness of Fit lainnya menunjukkan hasil CMIN/DF, RMSEA, TLI dan CFI yang good fit namun AGFI dan PNFI menunjukkan marginal fit. Berdasarkan hasil pengujian, model dikatakan fit. 
Tabel 2. Hasil Perhitungan Goodness of Fit

\begin{tabular}{|l|l|l|c|}
\hline \multicolumn{1}{|c|}{ Kriteria } & $\begin{array}{l}\text { Hasil } \\
\text { Model }\end{array}$ & $\begin{array}{c}\text { Nilai } \\
\text { Kritis }\end{array}$ & Kesimpulan \\
\hline chisquare & 972 & $<2 \mathrm{df}$ & good fit \\
\hline $\begin{array}{l}\text { CMIN/D } \\
\text { F }\end{array}$ & 1,66 & $\leq 2,00$ & good fit \\
\hline RMSEA & 0,067 & $\leq 0,08$ & good fit \\
\hline AGFI & 0,712 & $>0,8$ & marginal fit \\
\hline PNFI & 0,790 & $\geq 0,90$ & marginal fit \\
\hline CFI & 0,934 & $\geq 0,9$ & good fit \\
\hline
\end{tabular}

Kedua, pengujian validitas. Nilai loading factor dari semua indikator yang ada dalam model ditunjukkan pada tabel 3. Berdasarkan tabel tersebut ternyata semua nilai loading factor indikator $>0,50$. Sehingga indikator- indikator yang dipakai dalam penelitian ini telah memenuhi syarat untuk menjadi indikator konstruk kualitas, kepuasan pelanggan dan loyalitas. Sedangkan, hasil variance extracted, menunjukkan angka minimal 0,5 yang menunjukkan adanya convergent validity yang baik. Nilai variance extracted yang tinggi menunjukkan bahwa indikator-indikator itu telah mewakili baik secara variabel bentukan yang dikembangkan. 


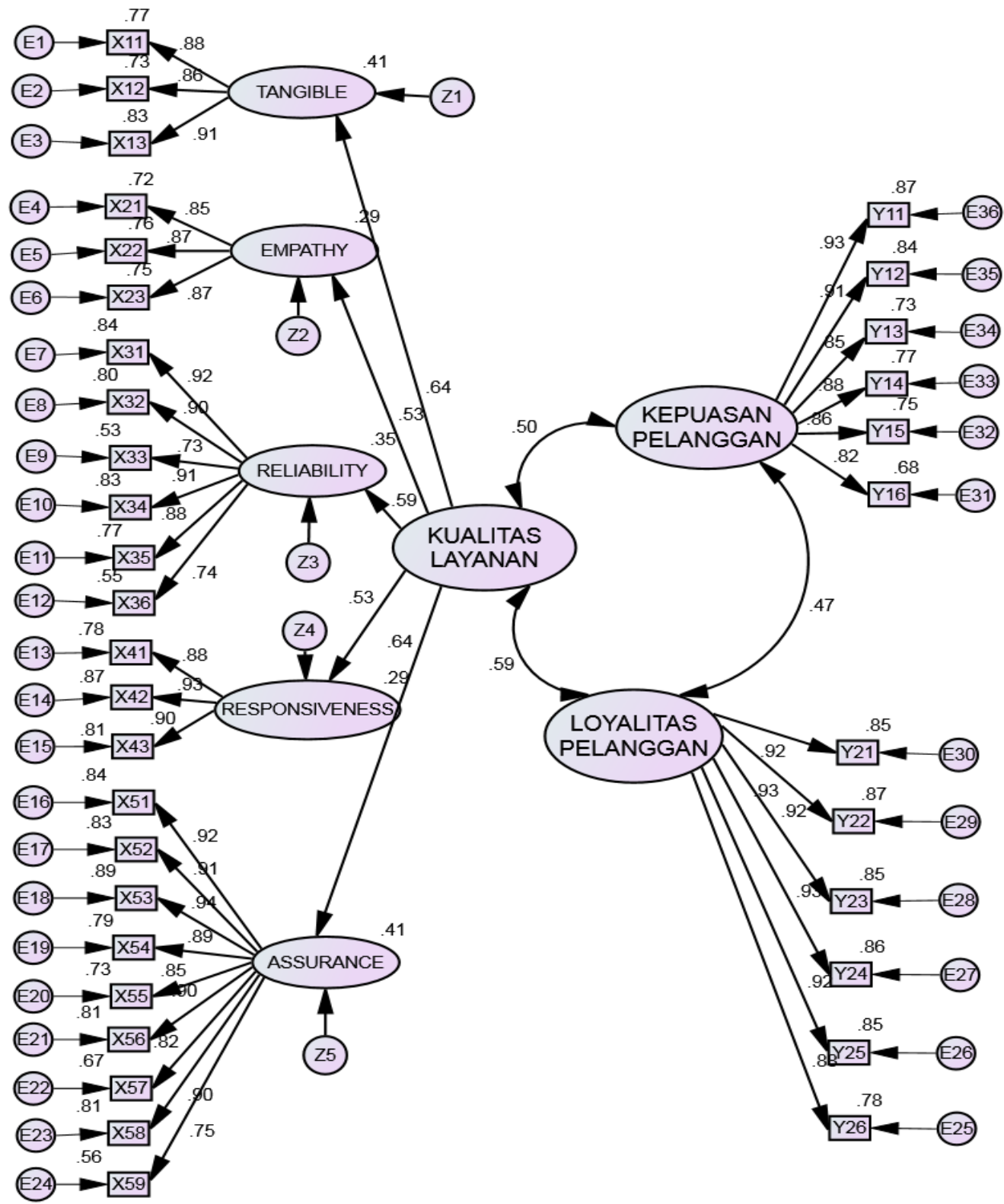

CHI-SQUARE $=972$

$\begin{array}{ll}\text { DF } & =586 \\ \text { RMSEA } & =0,067 \\ \text { GFI } & =0,746 \\ \text { AGFI } & =0,712 \\ \text { PNFI } & =0,790 \\ \text { CMIN/DF } & =1,66 \\ \text { TLI } & =0,929 \\ \text { CFI } & =0,934\end{array}$

Gambar 1. Measurement Model. 
Tabel 3. Nilai Loading Factor

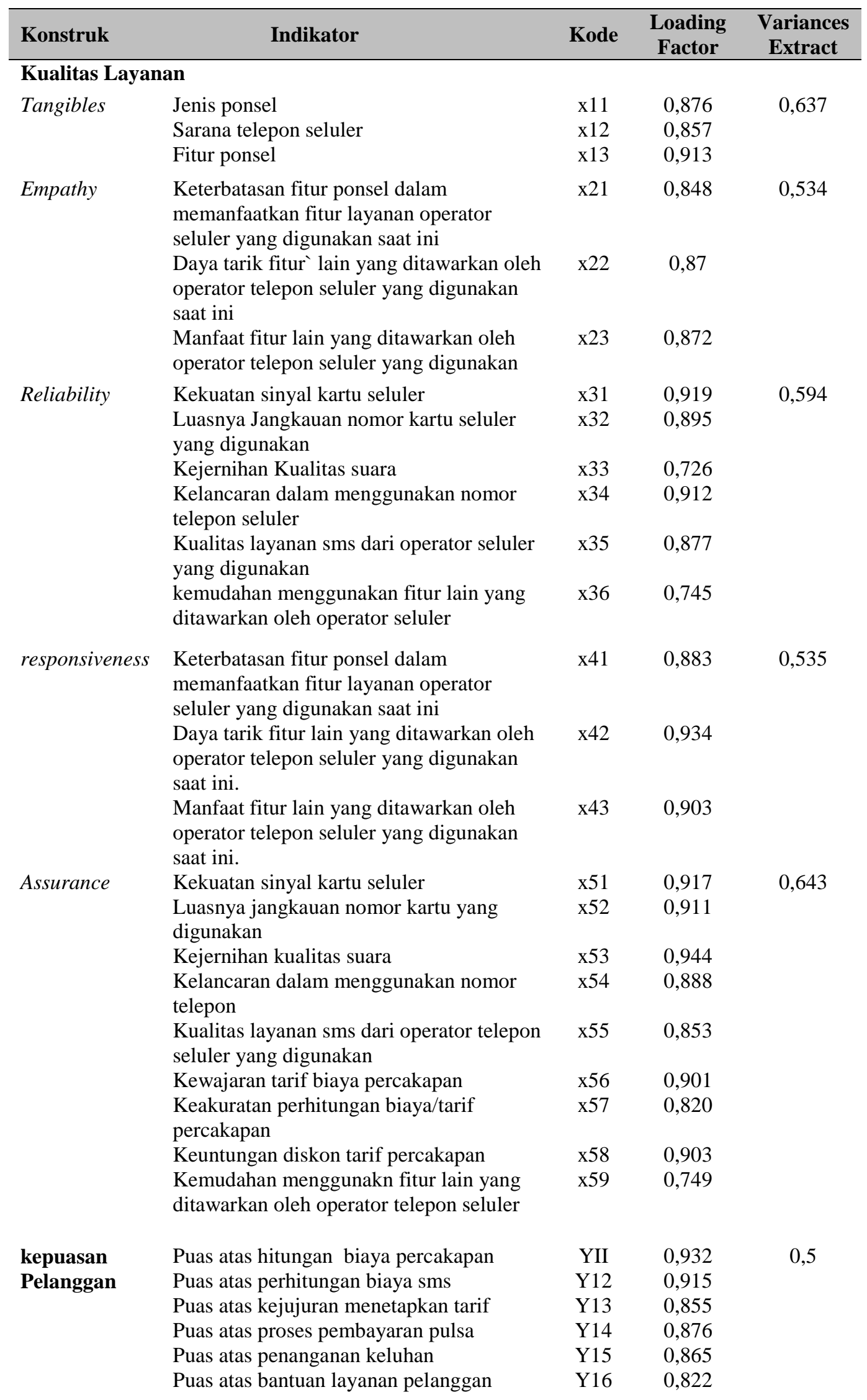




\begin{tabular}{llccc}
\hline Konstruk & \multicolumn{1}{c}{ Indikator } & Kode & $\begin{array}{c}\text { Loading } \\
\text { Factor }\end{array}$ & $\begin{array}{c}\text { Variances } \\
\text { Extract }\end{array}$ \\
\hline loyalitas & $\begin{array}{l}\text { Semangat untuk mengisi ulang pulsa } \\
\text { Pelanggan }\end{array}$ & Y21 & 0,924 & 0,59 \\
& $\begin{array}{l}\text { Semangat membeli kartu perdana yang } \\
\text { baru bila operator seluler yang digunakan } \\
\text { menawarkan promo/paket yang baru }\end{array}$ & Y22 & 0,933 & \\
& $\begin{array}{l}\text { Senang menggunakan fitur selain } \\
\text { percakapan dan sms yang ditawarkan }\end{array}$ & Y23 & 0,923 & \\
& $\begin{array}{l}\text { Senang memperbarui penggunaan fitur } \\
\text { Mereferensikan pada teman untuk } \\
\text { menggunakan kartu seluler yang digunakan }\end{array}$ & Y24 & 0,926 & \\
& Saat ini & 0,922 & \\
& $\begin{array}{l}\text { Semangat untuk menjelaskan kepada rekan } \\
\text { dan kerabat tentang segala keuntungan } \\
\text { yang terdapat pada kartu seluler yang } \\
\text { digunakan saat ini }\end{array}$ & Y26 & 0,882 & \\
\hline
\end{tabular}

Tabel 4. Hubungan Konstruk Berdasarkan Kovarians

$\begin{array}{lcr} & \text { Estimate S.E. C.R. } & \text { P Label } \\ \text { KUALITAS_LAYANAN } & \text { <-> KEPUASAN_PELANGGAN } & .187 .0464 .055 * * * \text { Par_32 } \\ \text { KUALITAS_LAYANAN } & \text { <--> LOYALITAS_PELANGGAN } & .227 .0514 .445 * * * \text { Par_33 } \\ \text { KEPUASAN_PELANGGAN } & \text { <-> LOYALITAS_PELANGGAN } & .404 .0834 .900 * * * \text { Par_34 }\end{array}$

Ketiga, pengujian reliabilitas. Hasil reliabilitas yang tinggi memberikan keyakinan bahwa indikator semua konsisten dengan pengukurannya. Hasil perhitungan construct reliability untuk setiap konstruk disajikan pada tabel 4. Construct reliability di atas 0,70 menunjukkan reliabilitas yang baik, Berdasarkan hasil perhitungan, semua konstruk dalam penelitian ini layak digunakan dalam model.

\subsection{Uji Structural Model}

\section{Tabel 5. Estimasi Parameter}

\begin{tabular}{|l|l|l|l|}
\hline \multicolumn{2}{|c|}{ Konstruk } & Estimasi \\
\hline $\begin{array}{l}\text { Kepuasan } \\
\text { Pelanggan }\end{array}$ & & Kualitas Layanan & 0,505 \\
\hline Reliability & & Kualitas Layanan & 0,594 \\
\hline Assurance & & Kualitas Layanan & 0,643 \\
\hline Tangibles & & Kualitas Layanan & 0,637 \\
\hline Empathy & & Kualitas Layanan & 0,534 \\
\hline Responsiveness & & Kualitas Layanan & 0,535 \\
\hline
\end{tabular}

\begin{tabular}{|l|l|l|l|}
\hline \multicolumn{2}{|c|}{ Konstruk } & Estimasi \\
\hline $\begin{array}{l}\text { Loyalitas } \\
\text { Pelanggan }\end{array}$ & & Kepuasan Pelanggan & 0,587 \\
\hline $\begin{array}{l}\text { Loyalitas } \\
\text { Pelanggan }\end{array}$ & & Kualitas Layanan & 0,466 \\
\hline
\end{tabular}

Hasil Estimasi pada tabel 5 didapatkan bahwa nilai estimate antar konstruk dan konstruk dengan dimensi hampir seluruhnya diatas 0,5. Sehingga didapat seluruh dimensi berpengaruh signifikan terhadap konstruknya.

\subsection{Pengujian Hipotesis}

Hasil pengujian terhadap hipotesis yang diajukan dalam penelitian ini secara ringkas ditunjukkan pada tabel 6 . Uji signifikansi bila disangkutkan dengan aktual penelitian ini, maka dapat disimpulkan sebagai berikut. 
Tabel 6. Hasil pengujian Hipotesis

\begin{tabular}{|c|c|c|c|}
\hline & Hipotesa & $\begin{array}{l}\text { Pengujian } \\
\text { hipotesa dengan } \\
\text { Amos v.22 } \\
\end{array}$ & Ringkasan Hasil \\
\hline $\begin{array}{l}1 . \text { Sem } \\
\text { semak } \\
\text { pelan }\end{array}$ & $\begin{array}{l}\text { kin tinggi kualitas layanan, } \\
\text { gan tinggi loyalitas }\end{array}$ & $\begin{array}{l}\text { C.R }=4,445 \\
\text { Estimasi } \\
\text { Parameter }=0,587\end{array}$ & 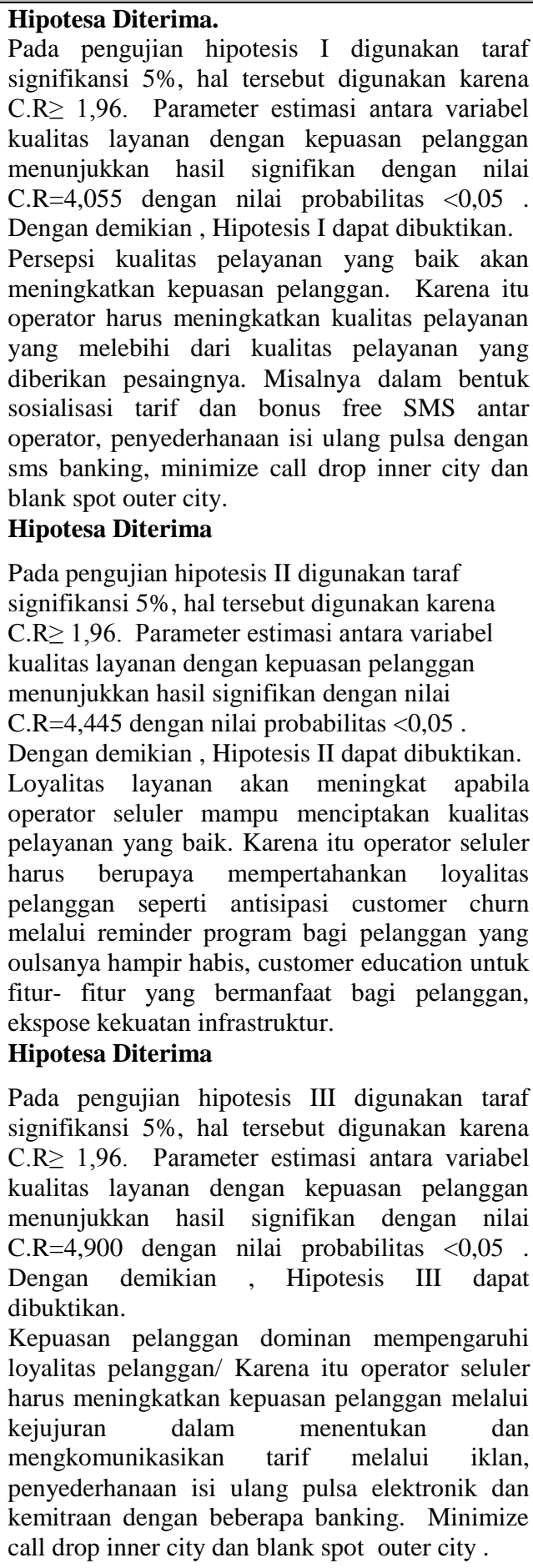 \\
\hline
\end{tabular}




\section{KESIMPULAN}

Hasil penelitian menunjukkan bahwa kelima dimensi pembentuk kualitas layanan terbukti berpengaruh secara signifikan terhadap kualitas layanan. Dimensi terkuat dalam menjelaskan kualitas layanan berturut-turut adalah assurance, tangibles, reliability, responsiveness dan yang terakhir empathy. Selain itu, hasil penelitian menunjukkan terdapat pengaruh yang kuat antara variabel kualitas layanan terhadap loyalitas pelanggan pada pelanggan Telkomsel di kota Cirebon. Hal ini terbukti dari hasil penelitian yang menunjukkan bahwa sebesar $58,7 \%$ variabel loyalitas pelanggan dapat dijelaskan oleh variabel kualitas layanan, sedangkan sisanya sebesar $41,3 \%$ dipengaruhi oleh faktor lain di luar variabel kualitas layanan. Dari penelitian ini diketahui pula bahwa terdapat pengaruh antara kualitas layanan terhadap kepuasan pelanggan pada pelanggan Telkomsel di kota Cirebon.hal ini terbukti dari hasil penelitian yang menunjukkan bahwa sebesar 50,5\% variabel kepuasan pelanggan dipengaruhi oleh kualitas layanan, sedangkan sisanya sebesar 49,5\% dipengaruhi oleh faktor lain diluar kualitas layanan. Hasil penelitian lain menunjukkan bahwa terdapat pengaruh antara kepuasan pelanggan terhadap loyalitas pelanggan pada pelanggan Telkomsel dikota Cirebon, namun tidak signifikan. Hal ini terbukti dari hasil penelitian yang menunjukkan bahwa sebesar 46,6\% variabel Loyalitas pelanggan dipengaruhi oleh kepuasan pelanggan, sedangkan sisanya $53,4 \%$ dipengaruhi oleh faktor lain diluar variabel kepuasan pelanggan.

\section{DAFTAR PUSTAKA}

Dwi Aryani \& Febri Rosinta (2010). Pengaruh kualitas layanan terhadap kepuasan pelanggan dalam membentuk loyalitas layanan. Jurnal Ilmu Administrasi dan Organisasi, Volume 17 No.2

Hajar Sasongko (2008). Analisis faktor yang mempengaruhi kompetensi tenaga penjualan untuk meningkatkan kinerja tenaga penjualan. Tesis. Semarang : Universitas Diponegoro

Hengky Latan (2013). Model Persamaan Struktural Teori dan Implementasi Amos 21, Bandung : Alfabeta
James A. Fitszimmons (2006). Service Management: Operations, Strategy, and Information Technology : Mc Graw Hill, fifth edition

Siswoyo Haryono \& Parwoto Wardoyo (2013). Structural Equation Modeling untuk Penelitian Manajemen Menggunakan Amos 18.00, Jakarta : Intermedia Personalia Utama

Riyad Eid (2013) Managing customer trust, satisfaction and loyalty through information communication technology:Business Science Reference (an imprint of IGI Global)

Waseso Segoro (2012). Kepuasan Dan Loyalitas Pelanggan: Dilengkapi Hasil Penelitian Pada Penyedia Jasa Telepon Seluler: Mitra Wacana Media 